Vol. 5, No. 1, 2019

Iryna Dyda

\title{
TO THE ISSUE OF URBAN SPACE IDENTITY: RELEVANCE OF THE DISTINCTION
}

\author{
Lviv Polytechnic National University \\ 12, S. Bandery Str., Lviv, 79013, Ukraine, \\ irdyda@gmail.com
}

Received: 20.02.2019/Revised: 04.07.2019/Accepted: 10.07.2019

(C) Dyda I., 2019

\begin{abstract}
Development of compositional characteristics of the urban environment in various countries has been characterized by a pervasive tendency to unification. In today's context, the main threat for the architecture is an absence of individuality. Support of the local identity of the architectural space is essential not only in the context of tourism, but, first of all, for the meaningful socio-cultural functioning of a country.
\end{abstract}

Key words: urban space, architectural identity, concept of environment formation.

\section{Introduction}

Since ancient times, approaches to formation of the urban space in the territory of Europe have been different. In various cultures, due to the influence of geographical and climatic situation, aesthetic and ideological social priorities and other factors, the urban space differed by density and height of buildings, percentage of green areas and their role in the architectural composition, by the character of planning, its association to the local landscape, etc. Together with special features of buildings themselves, these characteristics of the urban space essentially influenced formation of the architectural identity of the environment (B. Cherkes, 2008), which allows to identify the affiliation of a specific object with a certain country or national culture even after a brief inspection. Notwithstanding the broad range of possible variations of the architectural composition, there are two main concepts that incorporate these variations to a greater or a lesser extent.

One concept positions formation of the urban space as an open architectural composition connected with the local landscape. The other concept is based on the regular composition of self-sufficient closed spaces, where visibility of the surrounding landscape does not have a crucial significance. Each of these concepts of formation of the urban space provided the basis for the historically developed architectural identity of specific European territories.

In particular, the architectural identity of Ukrainian cities was developed on the basis of a close connection of architecture and landscape, preservation of open visual corridors, dispersed urban housing system interspersed with green areas and irregular picturesque composition of architectural ensembles (I. Dyda, 2009).

Urban environment in Southern and Western Europe was developed on the basis of the concept of formation of a system of closed interior spaces encompassed by densely built-up areas with high-rise buildings. This concept was especially distinct in the European territories that previously belonged to the Roman Empire in Italy, Spain, Portugal, France and other countries. Urban architectural space in these countries formed a basis for the concept of "a real European city". 
Traditional identity of the urban space in the specific zone is formed as a result of interaction of objective circumstances. Therefore, it is logical that the change of these circumstances leads to certain transformations of the identity of urban architectural space in such zone. The purpose of our article is to analyze trends of transformation of the architectural identity of cities in the Eastern and Western Europe, general tendencies of the modern development of this process.

\section{Basic Theory Part}

Urban architectural identity, which is autochthonous for the East-European territory and forms a basis for the concept of compositional cooperation of architecture and landscape, was preserved in the territory of Ukraine for a long time. According to bibliographic and iconographic sources, in particular sceneries of Ukrainian cities pictured on artists' paintings (Fig. 1-3), these peculiarities of architectural identity survived in the Ukrainian urban environment until the 18th - 19th century. Since that time, Ukrainian urban development was characterized by active tendencies to purposive harmonization of traditional city planning with regular classical schemes. According to V. Tymofiyenko et al. (2003, p. 246), based on the concepts of the Age of Enlightenment, urban compositions ought to correspond to the schemes of "ideal cities" developed in times of Renaissance and be characterized by a strict geometric shape that became a symbol of intelligence and harmony. Ideas of centralism, which emphasized order, were implemented gradually. In 1763, the Empress of Russia Catherine II issued a decree "On fulfillment of special plans for each governorate by all cities, their buildings and streets". As a result of this decree, practically all Ukrainian cities underwent radical replanning (Fig. 4, 5), and a concept of new replanning differed a lot from the historically developed concept in cities of Eastern Europe. These processes were ideologically grounded by a need of "Europeanization" of the urban space, its approximation to the WestEuropean standards. At that time, Western European countries were more successful in the economic aspect, and modification of the urban space according to the West-European standards had to prove the affiliation of a certain territory to this successful European cohort. It is important that appearance of such tendencies coincided in time with the loss of the state independence by Ukraine. The imperial government of Russia initiated change of concepts of formation of the architectural space of Ukrainian cities. Instead, both the community of Ukrainian architects and their construction customers showed dissatisfaction with such tendencies in the urban space as urban densification, separation of planning of street networks from the local landscape, formation of visually closed areas encompassed by high buildings, since they gradually and purposefully destroyed the traditional local architectural identity. V. Vecherskyi (2001, p. 227) gives documentary evidence of longstanding ignoring of new urban development approaches by local people. In particular, it concerned the decree on observing the single "red" line of street development. This issue had an essential meaning for the architectural identity of Ukrainian cities. Following the requirement on location of buildings in one even row along the straight prospect, the urban development composition, which was traditionally linked to the local landscape and created based on the sculpture landscape principle, could no longer preserve its irrational intrinsic character. In this case, the concept changed radically: from an irregular open composition - to a regular, metrical, closed one. Ukrainian writers expressed intuitive feelings of ordinary people. For example, Mykola Hohol, characterizing architectural reconstructions of Ukrainian cities in the classicism style, wrote: “... new cities have no appearance. They are so correct, so smooth, so monotonous, that after walking along one street you feel bored and refuse to peep into the next one. It is a row of walls and nothing more..." (V. Vecherskyi, 2001, p. 229). It should be noted that according to M. Hohol the main disadvantage of a new identity of the urban space was the absence of vivid visual impressions and features that could stick in one's memory for a long time and be associated with a specific city. 


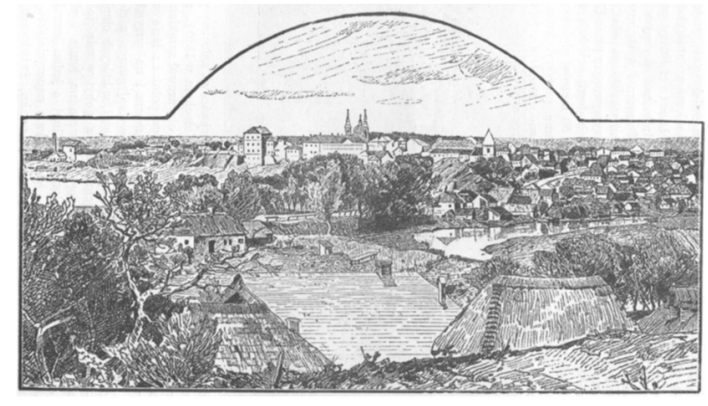

Fig. 1. The view of Ternopil, the 19th century (S. Majerski, 1900, t. II, p. 279)

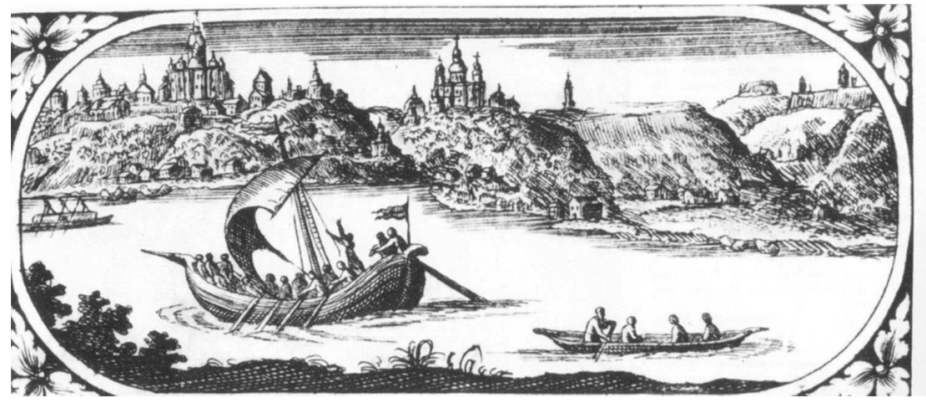

Fig. 2. The view of Kyiv, the 17 th century (V. Vechersky, 2003, p. 140)

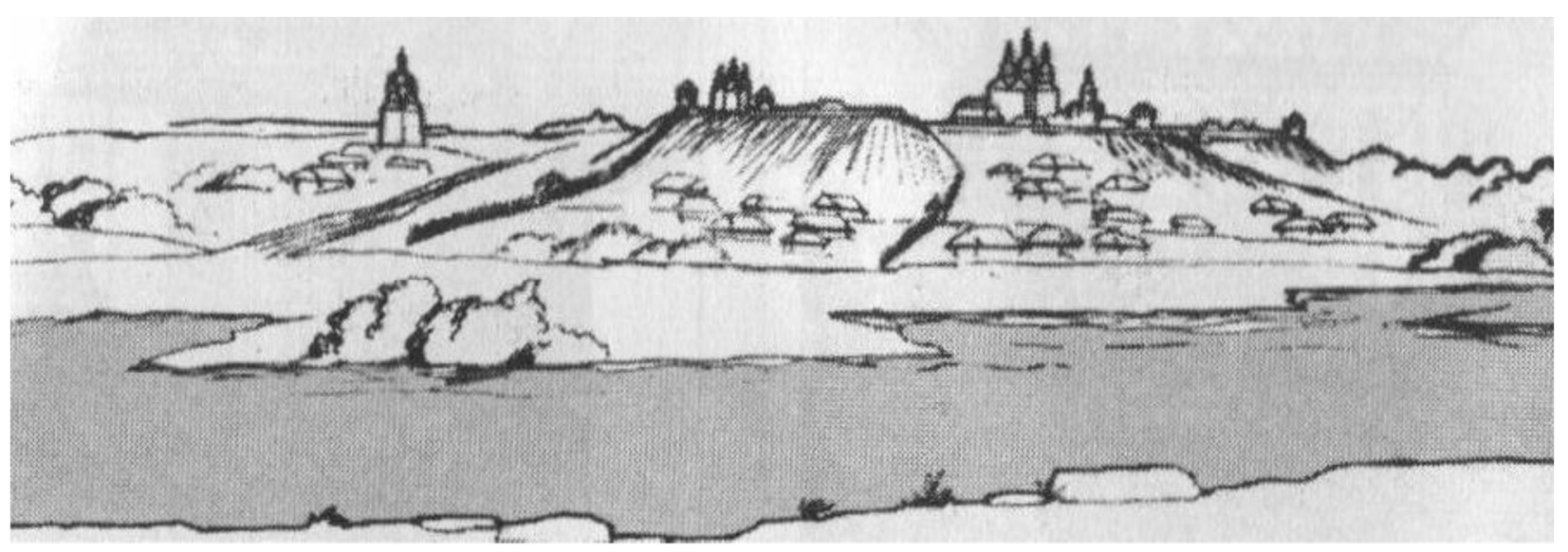

Fig. 3. The view of Romny in 1770: reconstruction by V. Vechersky (V. Vechersky, 2001, p.118)

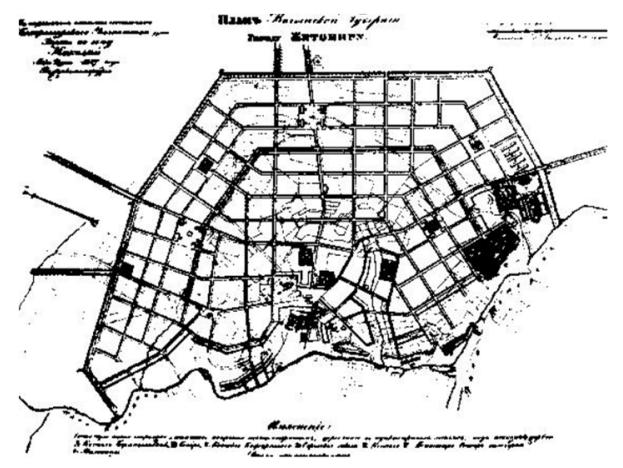

Fig. 4. Zhytomyr. Reconstruction project, 1827 (V. Tymofiyenko, red., 2003, p.266)

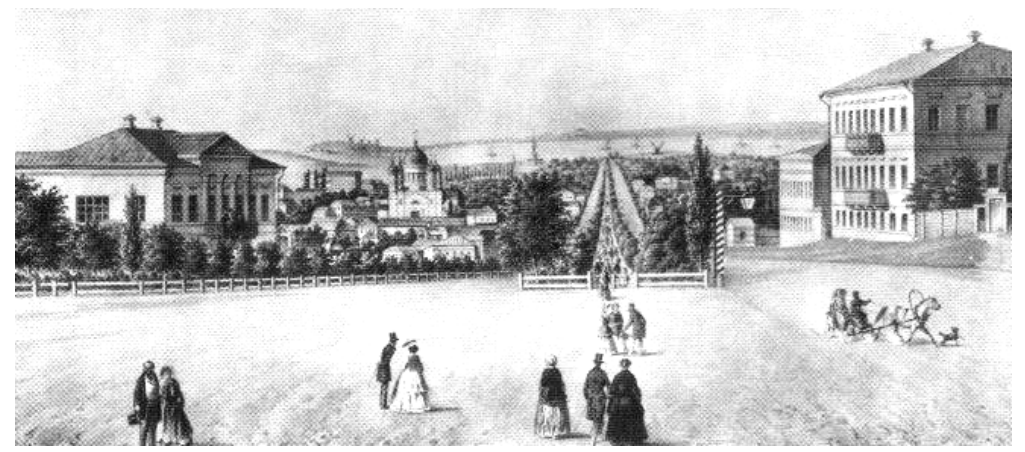

Fig. 5. Katerynoslav (now Dnipro) on the print of the 19th century (V. Tymofiyenko, red., 2003, p. 268)

In the Soviet period, the Ukrainian urban space continued to lose its traditional identity. Ideology of the hereditary evolution of urban development "was destroyed in the 1920-ies under the pressure of spiritual outbreak of the so-called Russian communism" (V. Vechersky, 2001, p. 230) and the historic nihilism penetrated into the architecture and urban planning for many decades, being inconsistent with the notion of the traditional architectural identity.

Although socio-economic, technical, and production factors (development of transport, increase in population, requirements of industrial production) undoubtedly actively impacted the change in the architectural identity of Ukrainian cities, the main accelerator of these changes was represented by an ideological factor in a form of outside authoritarian administrative influences dictated from above: at first by the Russian czarist regime, later on - by the Soviet government. Therefore, we have grounds to assume 
that in conditions of a stable statehood Ukrainian cities would have had a possibility to continue formation of the identity of their architectural space in line with the traditional concept of cooperation with landscape.

In contrast to Ukrainian cities, which were continuously changing in the period of last centuries due to objective external circumstances and systematic hostile interferences, cities of Western European countries had a possibility to develop their architectural space without an outside pressure, continued to freely apply their traditional compositional approaches and preserve local architectural identity. Traditional for the Western Europe peculiarities of the urban space were particularly clearly manifested on the South - in Italy, Spain, Portugal, France.

However, notwithstanding the favorable circumstances for preservation of the national architectural identity in West-European cities, it should be noted that theoretical works of urbanists of the end of the 19 th century also contain criticism of changes in the urban environment of Europe of that time. It is interesting that the main reason for dissatisfaction of scientists with the appearance of a contemporary city was its loss of the traditional local identity. It was emphasized that new European city planning involved a change in proportions of built-up areas and undeveloped lands. C. Sitte (1993, p. 135) writes: "A correlation between built-up and unbuilt areas in the modern city planning radically changed. Previously, a free space (streets and squares) was a closed integrated whole aimed at a certain artistic effect; now the whole territory is split into enclosed regular zones and spaces left between them are called streets and squares". Apart from that, C. Sitte (1993, p.135) is concerned about excessive introduction of green areas into the city space, planting of rows of high trees along the streets and around the perimeter of squares that, in his opinion, prevented from adequate perception of the composition of facades of city houses. C. Sitte explains such undesired changes by overindulgence of architects of that time by right angles and parallel planes that leads to appearance of visual corridors and impedes the formation of a traditional closed urban space. In the opinion of C. Sitte, such features as the straight line of uninterrupted housing, ideal visual closeness and compositional self-containment of spaces of urban squares created an image of a real European city. He wrote: "According to the historical principle of development, an uninterrupted line of housing that is still preserved in villages, closeness of space and artistic distinctiveness in old cities remain a starting point for all construction activities" (C. Sitte, 1993, p.151). As a positive example of an approach to formation of the architectural space, he cites the Bavarian Building Code of 1884 with its main aesthetic requirement: “...in composition of facades one should avoid anything that can ruin the symmetry and morality..." (C. Sitte, 1993, p.100).

In the traditional identity of a West-European city, green areas were never perceived as an equal and independent element of the urban space. They usually had a decorative role, only emphasizing and enriching the artificially created architectural space. From the perspective of such perception of the role of plants in the city, C. Sitte (1993, p.149) categorically protests against the mass appearance of high trees on the city streets and squares in the 19th century: "Huge monumental squares of the ancient age, medieval times and Renaissance were the centers of fine arts, mainly of architecture and sculpture. Planted trees, especially miserable unhealthy alleys of circular streets, stand in the way of such works of art... Maybe it would be better without them? What is a visually open square supposed to mean, if it is closed by leaves? It follows that trees should never be a visual obstacle...". Further, he cites such practical recommendations for architects: a row of trees should be interrupted before monumental buildings, since aesthetic losses from impossibility to perceive the facade are more essential in comparison with the little use of the greenery for the environment. Therefore, the architects should choose the lesser evil and refuse to plant trees on the city streets.

Analysis of these critical remarks shows that C. Sitte mostly worries not about the fact that the time brings certain changes in planning and architecture of his contemporary European city (for example, changes in the style of buildings or origination of some other concept of formation of the urban space). $\mathrm{He}$ is disturbed by the fact that the urban space loses its traditional features, which are replaced by "greyness", non-specificity, uncertainty of the urban composition, absence of certain characteristics that 
would define its identity. He does not like the fact that West-European cities lose traditional visually closed spaces, which are replaced by partially closed and partially open "intermediary" spaces; that rows of trees were planted on the paved, closed, interior in their nature streets and squares, where plants were previously used only for decoration of windows and balconies, and now these areas are no longer perceived as "urban interior" and became partially green, but yet far from being a blossoming garden. In view of these semi-steps towards an opposite compositional concept, a West-European city loses its identity, its image and specific beauty. In contrast to the situation in Ukrainian cities in the 19th century, these changes were not dictated by the desire of the state to borrow some more accomplished and popular way of urban space composition from neighboring countries. Obviously, in this case, there is some general tendency for transformation of the urban environment towards its unification.

In order to verify whether the evolution of architectural composition of spaces in West-European cities followed the direction described by Camillo Sitte, we can carry out a comparative analysis of iconographic materials. As we can see from old paintings and photos picturing panoramas of European cities of the end of the 19th - beginning of the 20th century, cities had few or no green zones at all. For instance, if we compare the panorama of Glasgow central street on the engraving of the 19th century with its modern appearance, we can see that a row of trees was planted along the street that now became a pedestrian one. The same tendency can be revealed concerning Puerta del Sol in Madrid (S. Majerski, 1900, p. 80). As compared to the image on the graphical painting of the 19th century, modern wide open space of the square is filled with numerous elements of the urban design (Fig. 6, 7). In conditions of the hot climate, tree plantations are rather scarce here, however new elements such as billboards, small architectural forms, street lamps have the same visually destructive function in the compositional aspect as rows of trees in critical remarks of C. Sitte, i.e. hinder perception of the historic development of the square as a uniform architectural ensemble. The book "Opis ziemi" (S. Majerski, 1900, p. 89) gives a graphic image of the panorama of Lisbon of the 19th century. It pictures no tree at all. Certainly, it does not mean the real absence of any green areas in the city of that time, however it proves that trees had no meaning for the architectural identity of Lisbon (as a comparison, it would have been impossible to picture the panorama of Kyiv of the 19th century without large-scale areas of planting, since the nature component was very significant for the architectural identity of the Ukrainian capital (Fig. 2). Green areas on the photos picturing panoramas of modern Lisbon are more noticeable.

In the 20th century, a tendency to introducing green areas reached the USA. For example, in the book "Chicago then and now" (E. McNulty, 2000) picturing old photos of separate architectural landscapes of Chicago accompanied by modern images of these places, we can see that more trees and vertical greenery on facades appeared at the beginning of the 21 st century, and due to this fact the buildings themselves are perceived fragmentarily. For example, at the end of the 19th century the building of St. Ignatius College had no tree around, so all facades were fully perceived by people walking by. Instead, the photo of the end of the 20th century pictures a row of trees that partially close the half of facades of buildings (Fig. 8). A similar situation can be observed on the square near Dearborn railway station, Franklin Company building, Presbyterian Church on Michigan Avenue, on the so-called "Street of Forty Doors" created by blocked workers' houses designed by architect Joseph Brompton in 1904 (E. McNulty, 2000 , c. 46 , c. 47 , c. 48 , c. 49 , c. 62 , c. 63 , c. 118 , c. 119), and other images. Apart from trees, new buildings appeared in the midst of many old houses, visually competing with them. As a rule, they are higher, more ponderous and compositionally standard, therefore, they often turn into visually aggressive planes that prevent from adequate perception of a historical object. Transport system also adds to an effect of visual discomfort of the modern urban environment. Its destructive impact on perception of the architectural ensemble manifests in two ways: a) directly, when high buses or trucks close the facades; b) indirectly, when quick movement of vehicles on the streets distracts attention and does not allow to concentrate on perusal of architecture. 
Therefore, one can assert that the character of the urban space in those countries that developed its architectural space without an outside ideological pressure has been also gradually changing during the last century, estranging itself from the initial compositional principles.

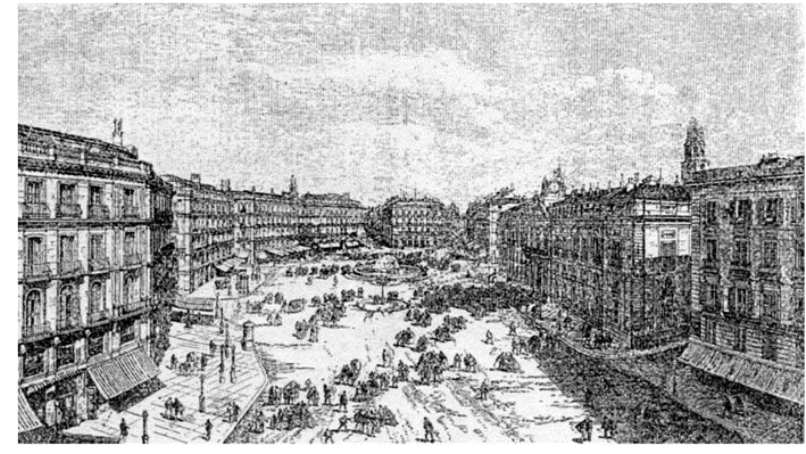

Fig. 6. Madryt, the 19 th century (S. Majerski, 1900, p. 80)

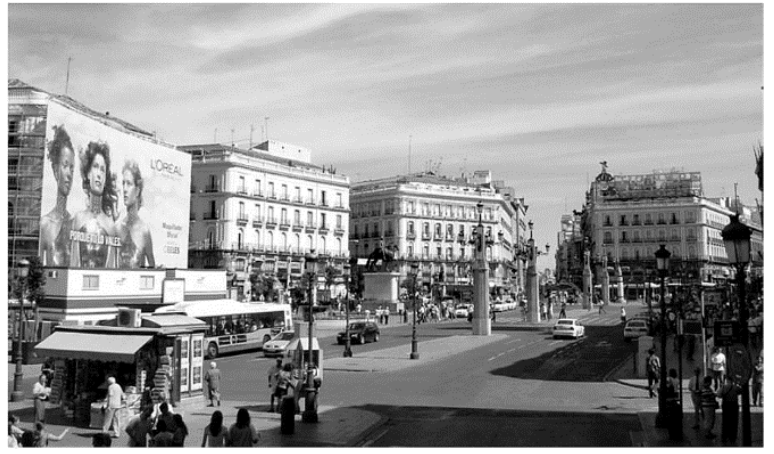

Fig. 7. Puerta del Sol in Madrid, the 21st century (https://ispaniagid.ru/puerta-del-sol-serdtse-madrida/)
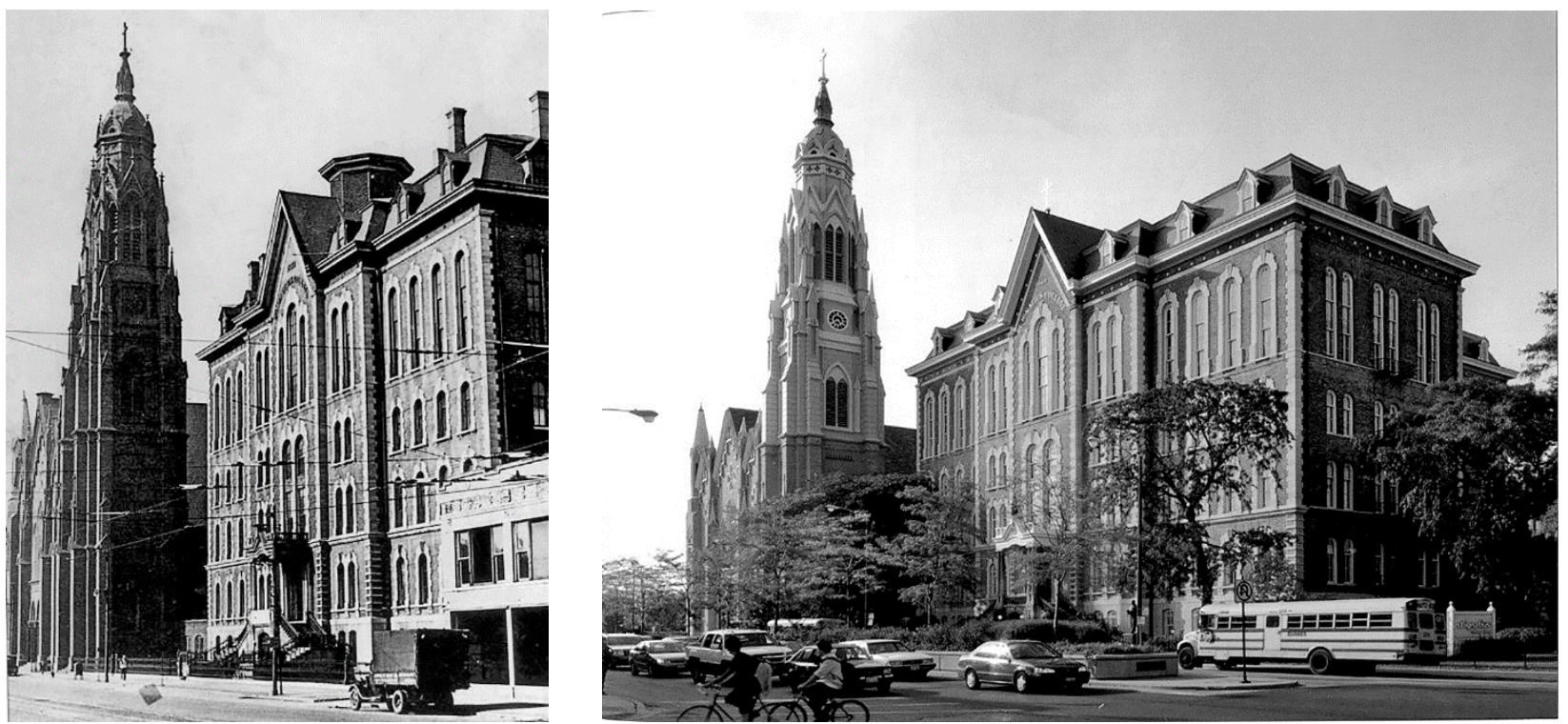

Fig. 8. The building of St. Ignatius College (Chicago) at the end of the 19th century and in the end of the 20th century (E. McNulty, 2000, pp. 98, 99)

\section{Results and Discussion}

At first sight, these compositional changes that took place in the urban environment of Ukrainian cities in the 19-20th centuries and changes in the urban space of West-European cities differ greatly in a qualitative aspect. Ukrainian cities that initially appeared as an architectural and landscape ensemble, where green areas and nature elements had a significant compositional and even utilitarian function (defensive, memorial, symbolical), suffered transformations towards an increase of density and height of buildings, reduction of green zones. It led to the visual closeness of urban spaces and loss of visual connections with the landscape, while regular geometric planning of streets was leading to the loss of interconnection between street tracing and local relief. Cities of the West-European type, which originated as a complex of visually closed spaces encompassed by densely built-up areas and designed on the basis of a rational geometric approach to planning with minimal quantity of green zones within the city territory, underwent transformations towards expansion of the city territory, 
inclusion of open green areas, formation of a visual connection of the city center with the surrounding landscape, planting of trees on city streets.

However, if we analyze these changes in the context of their non-material, visually sensual result, in the context of their impact on the condition of the architectural identity of the urban environment, we can assert that they are very similar. Processes taking place in the urban environment of West-European cities, criticized by C. Sitte (1993, c. 135), are actually a mirror reflection of parallel processes in Ukrainian cities. In both cases, their action had a centrifugal direction: from the space with distinct characteristic features to the space, in which these features become more and more indistinct, vague and unnoticeable. As a result, irrespective of the initial compositional characteristics of the traditionally formed environment in a certain country, for the last two centuries they have been complemented with their antipodes, and the image of the urban space in various countries approaches a certain average level, where neither of characteristics is pronounced strongly enough to become a basis of the architectural identity of the environment.

At the modern stage of urban development, when new construction in the whole world follows a similar technology, when the same popular design bureaus with clear stylistic and aesthetic priorities receive orders in cities of various countries, when famous trade companies, having developed the unified style of their buildings with an advertisement purpose, place them into the environment of different country - the process of losing the national architectural identity actively continues. Taking into account the pace of construction and dimensions of modern buildings, new elements of city architecture will have a visual advantage in the near future in every country of the world. Globalization of the city space and its negative socio-cultural impact is a long-recognized world problem. To a certain extent, it can be neutralized through a revival of a traditional local concept of formation of the urban space with the help of modern architectural and constructive possibilities and resources. There are scientifically proven arguments for preservation and targeted formation of a local territorial identity, in particular in the economic aspect - as a precondition of an efficient development of the tourism industry.

Architectural identity of an environment is a result of a complex interaction of material and social factors, objective and subjective circumstances. Among numerous factors such as, for instance, economic, technological, climatic, historical ones that cannot be impacted by a local architecture, there are factors belonging to a psycho-emotional realm. Namely, these factors have a certain potential to influence the choice and use of a certain concept of formation of the urban space, since every nation or ethical group expresses its identity in its own architecture, while presence of local traditions in the architecture evolves, in its turn, into an important factor of support and development of a local identity. Emotional, educational and psychological impact of the architectural space allows to draw some parallels between the architecture and language. Architectural forms, architectural composition help to convey understanding of aesthetic priorities, moral principles, even a behavioral model. Unlike the verbal language, the architectural language has a very long history of existence; and in contrast to the literature, the architecture is more cooperative irrespective of the human desire. The expression "Hic mortui vivunt et muti loquuntur" (Here the dead live; here the mute masters speak") on the wall of the library of Lviv Polytechnic National University is very appropriate for characteristics of the architectural environment. Therefore, certain social processes taking place in the language environment have their reflection in symbolics of architectural forms. In particular, in conditions of absence of statehood, more wealthy and educated groups of local population as a rule speak the language of a dominating country in order to achieve a certain social status. A similar phenomenon can be observed in the sphere of architecture, when less successful countries try to copy the architectural environment of those countries that have the biggest economic and political influence. In such a manner, they want to improve their image and raise their self-esteem. For a long time, Ukrainian architecture tried to follow foreign examples, and this practice also did not do any good to preservation of the local architectural identity. In recent years, increased social consciousness and interest in the national arts and culture created preconditions for positive improvements in the aspect of the Ukrainian architectural identity. However, since qualitative changes in the architecture have significant 
inertia, efficient implementation of these changes requires efforts on the part of both architects and state government institutions. Due to the huge emotional and educational potential of the architectural space, support and development of its own traditional identity have a crucial significance for survival of the state, first of all, in the socio-cultural aspect.

\section{Conclusions}

Therefore, identity of the architectural environment in territories with its own historically developed architectural traditions and original concepts of composition of the living space, which in architectural and urban development aspect significantly differed by many distinctive features, has been consistently moving towards mutual rapprochement, a certain "common denominator" for the last two centuries. In the architectural space of modern cities, irrespective of their geographical location and historical circumstances, there is a continuous general tendency for transformation of the urban environment towards its unification.

In summary, the same shared threat for the architectural space of any country exists in modern times a loss of the traditional identity as a result of an absence of individuality. Therefore, efforts to copy foreign architectural examples, even the best ones, only worsen the situation leading to further unification of the space. Later on, it may lead to real economic losses of local budgets due to the lost opportunity to earn on the international tourism. Apart from that, because of this "strategy of borrowing ideas" the potential of emotional impact of a new standardized architectural space will form a cosmopolitan "citizen of the world", not a conscious citizen of the motherland.

Therefore, it would be expedient to choose a search for methods of formation of the modern urban space on the basis of local architectural traditions as the main direction of scientific studies in the theory of architecture and urban studies, to pave our own way in the architectural space composition, using achievements of other countries for a comparative control of the quality of practical implementation of architectural projects.

\section{References}

[1] Cherkes B. 2008. Nacionalna identychnist v arkhitekturi mista. Lviv: Natsionalnyj universytet "Lvivska politehnika".

[2] Dyda I. 2009. Ekologichni osnovy tradycijnoji ukrajinskoji arkchitektury. Lviv: Natsionalnyj universytet "Lvivska politehnika".

[3] Majerski S. 1900. Opis ziemi. T. II. Wiedeń: Franciszek Bondy.

[4] McNulty E. 2000. Chicago then and now. San Diego: Thunder Bay Press.

[5] Sitte C. 1889. Stadte-bau nach seinen kunstlerischen grundsatzen. Wien: Carl Graeser (russian translation 1993. Moskwa: Strojizdat).

[6] Tymofiyenko V., red., 2003. Istoriya ukrayinskoyi arkhitektury. Kyiv: Tehnika.

[7] Vecherskyj V. 2001. Arkhitekturna i mistobudivna spadshchyna doby Hetmanshchyny. Kyiv: NDITIAM. Vecherskyj V. 2003. Spadshchyna mistobuduwannia Ukrainy. Kyiv: NDITIAM.

Ірина Дида

\section{ДО ПРОБЛЕМИ ІДЕНТИЧНОСТІ МІСЬКОГО ПРОСТОРУ: АКТУАЛЬНІСТЬ ІНДИВІДУАЛЬНОСТІ}

Анотація. Архітектурна композиція міського простору $і$ окремих його складових елементів під впливом об'єктивних обставин, починаючи з ХІХ ст., в иілому світі демонструє тенденцію до взаємного образного зближення. В Украйні иілеспрямоване перепланування міст на «європейський» лад призвело до втрати більшості традиційних для украӥнських міст характеристик, основою яких був композиційний і візуальний зв'язок архітектури з ландиафтом. Вважається, що це стало наслідком авторитарних адміністративних впливів в умовах відсутності власної державності, адже тоді відкидали проекти, зроблені украйнськими архітекторами згідно з місиевими містобудівними традиціями, а 
перевагу надавали класичним пропозиціям архітекторів з Москви і Петербурга. В той час західноєвропейські краӥни мали можливість розвивати архітектурний простір міст без стороннього тиску, згідно зі своїми власними поглядами $i$ традииіями. Але, незважаючи на такі сприятливі обставини, в кінці XIX ст. міське середовище тогочасної Свропи часто піддавалось критиці за втрату місцевої ідентичності. Якщо простір українського міста трансформувався у напрямі ущільнення забудови і втрати візуальних зв'язків з ландшафтом, то простір західноєвропейського міста змінювався у протилежному напрямі - через впровадження відкритих озеленених територій і втрату візуальної закритості міського простору - основної ознаки його архітектурної ідентичності. Отже, йдеться про загальну тенденцію до уніфікаиії композичї міського простору, яка почала проявлятися в ХІХ ст і триває дотепер. Незалежно від первісних композиційних характеристик середовища, їх поступово доповнюють їхні антиподи, наближаючи місто до певного середньостатистичного рівня, де жодна з характеристик не є настільки яскраво вираженою, щоб стати основою архітектурної ідентичності. У підсумку в сучасних умовах для архітектурного простору міста будь-якої країни існує спільна загроза - втрата традииійної ідентичності через відсутність індивідуальності.

Ключові слова: архітектурне середовище, ландщафт, урбаністична композиція. 